\title{
IMPACT OF HIGHER EDUCATION ON SOCIO-ECONOMIC DEVELOPMENT
}

\author{
IMPACTO DA EDUCAÇÃO SUPERIOR NO DESENVOLVIMENTO \\ SOCIOECONÔMICO \\ IMPACTO DE LA EDUCACIÓN SUPERIOR EN EL DESARROLLO \\ SOCIOECONÓMICO
}

\author{
Elena V. FAKHRUTDINOVA ${ }^{1}$ \\ Julia S. KOLESNIKOVA ${ }^{2}$ \\ Natalia I. LARIONOVA ${ }^{3}$ \\ Lyubov G. CHUMAROVA ${ }^{4}$
}

\begin{abstract}
In the article it is studied the influence of higher education on the development of regional socio-economic systems. Economic and statistical analysis revealed the impact of measures of higher education development on the GRP (gross regional product) of the region. Highly significant factors were: salaries of faculty staff of the universities and internal research and development costs. These indicators indirectly reflect the degree of intellectual development in the region and show the impact of intellectual capital development on socioeconomic development. University professors develop students' knowledge, which allows them to institutionalize higher education and spread it in the region. The quality of a university professor's intelligence directly affects the formation of intellectual capital in the region. In addition, it was significant the number of students studied in bachelor's, specialty, and master's programs. Moreover, the higher the number of students per capita, the lower the GRP per capita, which is explained by their low incomes. In the article it was considered the differentiation of Federal districts and regions of the Russian Federation in terms of the development of the higher education system. Methods of dividing indicators and grouping were applied, which made it possible to make cartograms and visualize the differentiation of regions by the number of higher education institutions and by the number of graduates.
\end{abstract}

KEYWORDS: Higher education. Regional socio-economic development. Intellectual capital. Research and development. Indicator.

1 Kazan Federal University, Kazan - Russia. ORCID: https://orcid.org/0000-0003-0293-8599. E-mail: efahr@mail.ru

2 Kazan Federal University, Kazan - Russia. ORCID: https://orcid.org/0000-0003-3073-100x. E-mail: hulia k@mail.ru

${ }^{3}$ Kazan Federal University, Kazan - Russia. ORCID: https://orcid.org/0000-0003-4668-6717. E-mail: natashalari@mail.ru

4 Kazan Federal University, Kazan - Russia. ORCID: https://orcid.org/0000-0002-5693-8925. E-mail: lgchumarova@kpfu.ru

RPGE- Revista on line de Política e Gestão Educacional, Araraquara, v. 25, n. esp. 6, p. 3472-3482, Dec. 2021. e-ISSN:1519-9029 
RESUMO: No artigo estuda-se a influência da educação superior no desenvolvimento dos sistemas socioeconômicos regionais. A análise econômica e estatística revelou o impacto das medidas de desenvolvimento do ensino superior no PBR (produto bruto regional) da região. Os fatores altamente significativos foram: salários do corpo docente das universidades e custos internos de pesquisa e desenvolvimento. Esses indicadores refletem indiretamente o grau de desenvolvimento intelectual da região e mostram o impacto do desenvolvimento do capital intelectual no desenvolvimento socioeconômico. Os professores universitários desenvolvem o conhecimento dos alunos, o que lhes permite institucionalizar o ensino superior e divulgá-lo na região. A qualidade da inteligência de um professor universitário afeta diretamente a formação de capital intelectual na região. Além disso, foi significativo o número de alunos cursados nos programas de bacharelado, especialidade e mestrado. Também, quanto maior o número de alunos per capita, menor é o PBR per capita, o que se explica por sua baixa renda. No artigo foi considerada a diferenciação dos distritos federais e regiões da Federação Russa em termos do desenvolvimento do sistema de ensino superior. Foram aplicados métodos de divisão de indicadores e agrupamento, que permitiram fazer cartogramas e visualizar a diferenciação das regiões pelo número de instituições de ensino superior e pelo número de concluintes.

PALAVRAS-CHAVE: Ensino superior. Desenvolvimento socioeconômico regional. Capital intelectual. Pesquisa e desenvolvimento. Indicador

RESUMEN: En el artículo se estudia la influencia de la educación superior en el desarrollo de los sistemas socioeconómicos regionales. El análisis económico y estadístico reveló el impacto de las medidas de desarrollo de la educación superior en el PRB (producto regional bruto) de la región. Los factores altamente significativos fueron: los salarios del personal docente de las universidades y los costos internos de investigación y desarrollo. Estos indicadores reflejan indirectamente el grado de desarrollo intelectual en la región y muestran el impacto del desarrollo del capital intelectual en el desarrollo socioeconómico. Los profesores universitarios desarrollan el conocimiento de los estudiantes, lo que les permite institucionalizar la educación superior y difundirla en la región. La calidad de la inteligencia de un profesor universitario afecta directamente la formación de capital intelectual en la región. Además, fue significativo el número de estudiantes que estudió en los programas de licenciatura, especialidad y maestría. Además, cuanto mayor es el número de estudiantes per cápita, menor es el PBR per cápita, lo que se explica por sus bajos ingresos. En el artículo se consideró la diferenciación de los distritos federales y las regiones de la Federación de Rusia en términos del desarrollo del sistema de educación superior. Se aplicaron métodos de división $y$ agrupamiento de indicadores que permitieron realizar cartogramas y visualizar la diferenciación de regiones por el número de instituciones de educación superior y por el número de egresados.

PALABRAS CLAVE: Educación superior. Desarrollo socioeconómico regional. Capital intelectual. Investigación y desarrollo. Indicador. 


\section{Introduction}

Universities as a factor of territorial development have been studied from the 50s of the XX century and some of the government actions taken at the state level on the basis of research data allowed us to obtain effective results. Currently, both developed and developing countries are increasing public spending on higher education. A. Madison found out a relationship according to which an increase in budgetary funds for education by $1 \%$ leads to an expansion in the country's gross domestic product by $0.35 \%$ (MADDISON, 1991). In 1975, the professor at Harvard University Ya. Mincer also proved that getting an education is an investment of students in themselves. According to his calculations, each additional year of study increases a person's income by up to 7\%. Using mathematical models L. Lockner proved that subsidies to education can reduce criminality (LOCHNER, 2004). According to his data, if a person has a higher education, it reduces his predisposition to all types of crimes. Increasing the accomplishment of a society for 1 academic year provides an increase in the economy by $5 \%$ in the short term and by $2.5 \%$ in the long term (OECD data) (TROKHIMCHUK, 2017).

According to research by the G. G. Zubritskaya, the increase the number of people aged 15-64 with higher education by $1 \%$ can rise the life expectancy of the population by 0.33 years and reduce the number of crimes by $3.8 \%$ during the year; increase an average monthly income per person by 0.4 dolars can lead to an increase in the number of people aged 15-64 years with higher education by $0.02 \%$; the growth of unemployment by $1 \%$ leads to an increase in criminal offenses by $5.97 \%$ for the year and growth in the population aged from 15 to 64 years with higher education 0.3\% (HUANG; QIN, 2018).

The quality, level and accessibility of education of the population in the modern world are fundamental sources of economic development of territories. Russia is in the second place among the countries with the number of people with higher education (62.7\%) aged 25-64 years, after South Korea where people with higher education are 69.6\%.

Fundamental approaches to the relationship between economic growth and education are laid down in the works of F. Altbach, L. Walras, D. Weil, M. Woodhall, E. Denison, J. Kendrick, N. Fischer, B. Fraumeni, M. L. Agranovich, Y. S. Vasiliev, N. V. Zubarevich (ZUBAREVIC, 2019).

The interconnection of education and the development of human capital is studied in the works of P. Bourdieu, G. Becker and J. Coleman (BOURDIEU, 2019). It is necessary to note domestic scientists who pay attention to this problem, it is worth noting E. V. Anishin, E. A. Egel, V. V. Radaev, A.V. Fakhrutdinova, O. A. Shlyakov (FAKHRUTDINOVA, 2012). 
However, the impact of specific indicators of higher education on regional socioeconomic development is still not fully studied and it requires additional analysis of the differentiation of regions according to the indicators of their higher education development, which affects the potential for regional development. In the context of digitalization of the economy, the intangible benefits generated by the Institute of higher education become the most important part of the national wealth.

\section{Methods}

The study was based on approaches that defined its purpose and objectives. An institutional approach to the analysis of higher education is applied. The institutional approach also allows us to consider the institutionalization of intangible capital through science and higher education. The balance approach is applied to the study in evaluating indicators of higher education using statistical indicators and building economic and statistical models. Methods of empirical research allowed us to offer a classification of regions of the Russian Federation by higher education enrollment rate. The analytical-comparative method with the use of inductive knowledge applied in the analysis of indicators of development of higher education, such as: the number of educational institutions, number of faculty, number of students at various educational levels, the number of organizations engaged in scientific research and development, the number of personnel involved in scientific research works, research and development costs, patent applications, salaries of university staff. Economic and statistical research methods were aimed at identifying the interaction detection between the indicators and GRP per capita for the period 2015-2018. We used a regression model of panel data with random effects, which allows us to consider unobservable processes. The sample size was 291 observations, the F-test and the Hausman test showed the consistency of the model, and the coefficient of determination was 0.8 .

\section{Results and Discussion}

Regions have heterogeneity in higher education rate, a general trend in the period 20152018 was a consolidation of higher educational institutions. The largest number of higher educational institutions is represented in Moscow, Saint Petersburg, Krasnodar, Primorsky and Stavropol territories, the Republic of Tatarstan, Novosibirsk and Sverdlovsk regions. Similarly, the distribution of faculty staff and students in higher education institutions is presented. 
However, in Saint Petersburg and the Rostov region, there is an increase in the number of students, with a stable decrease in the number of teachers, which may negatively affect the quality of education in these regions. The highest indicators of the number of students per faculty staff in the period 2015-2018 are presented in the Republic of Tatarstan - 19.9; Sverdlovsk region-19.4; Stavropol territory-18.6 5 .

If we consider the indicators of GRP per capita in the regions of the Russian Federation, excluding oil-producing regions such as the Nenets Autonomous district, the Tyumen region, the Republic of Sakha (Yakutia), and others, the next leading group are the regions with a large number of students and educational organizations. We built a regression model of panel data with random effects, presented in table 1 . Some of the coefficients that have monetary units of measurement were taken logarithms to obtain objective coefficients.

Table 1 - Regression model of the dependence of the socio-economic situation of the region and indicators of higher education

\begin{tabular}{|c|c|c|}
\hline gross regional product per capita & Coef. & Coef. Std. Err. \\
\hline number of higher educational institutions & $-0,0013$ & 0,0009 \\
\hline number of faculty staff & $0,0000^{*}$ & 0,0000 \\
\hline $\begin{array}{c}\text { the number of students study in bachelor's, specialist's, } \\
\text { and master's programs per 10,000 population }\end{array}$ & $-0,0007^{* *}$ & 0,0002 \\
\hline organizations that performed research and development & 0,0002 & 0,0000 \\
\hline $\begin{array}{c}\text { The number of staff involved to the research and } \\
\text { development work }\end{array}$ & $-0,0000$ & 0,0168 \\
\hline Internal research and development works costs & $0,0630^{* * *}$ & 0,0242 \\
\hline salary of higher education teaching staff & $0,4046^{* * *}$ & \\
\hline $\mathrm{R}^{2}$ & 0.8 & 291 \\
\hline $\mathrm{N}$ & & \\
\hline
\end{tabular}

Source: Devised by the authors

The model showed a strong impact of research and development costs and higher education faculty staff's salaries on GRP per capita in the region, with the level of wages having a greater impact. Research expenditures indicate the development of intellectual capital in the region, which allows it to achieve competitive advantages in the conditions of the fourth industrial revolution. The wage index shows the quality and specificity of human capital (KOLESNIKOVA; FAKHRUTDINOVA; ZAGIDULLINA, 2016). Professors form students ' knowledge, which allows them to institutionalize higher education and spread it in the region. 
The quality of a university teacher's intellectual capital directly affects the formation of intellectual capital in the region. The number of students has the opposite effect on GRP, which is explained by low incomes during the study period.

The labor potential of the region is formed in the higher education system (KARASIK et al., 2015). An important figure of its formation is the number of graduates of higher educational institutions.

In order to analyze the differentiation of districts and regions of the Russian Federation in terms of higher education coverage, the following indicators were calculated and presented:

* number of graduates of higher educational institutions (thousand people);

* number of higher education institutions per 10,000 inhabitants.

To describe the work, it was taken into account the data of the number of graduates of higher educational institutions of the Russian Federation for period of 2015 - 2018. For the analytical report it was used 2 tables with data, where the first (left) are all subjects of Russia, and on the other (right) all entities, except Federal cities (Sevastopol, Moscow, SaintPetersburg), as well as entities with a constant zero value for the entire study period.

As a method of dividing indicators, it was chosen an equal interval, which was calculated using the formula:

Interval value $=(\mathrm{Xmax}-\mathrm{Xmin}) /$ number of intervals $(1)$

It was decided to take a 5-interval division of indicators, which in each year had its own value.

Based on the obtained data, we can conclude that all subjects are in the very first zone with approximate indicators from 0.1 to 45 thousand graduates. Next the city of Saint Petersburg is in the range from 33.7 to 89.8 , where in 2018 the Republic of Tatarstan was included. Then it is a huge gap where there is no single region in points 3 and 4. Moscow always has the highest indicators in the range from 186 to 2024 thousand graduates. It can be noted that in all regions and cities the maximum rate in the number of graduates was recorded in 2015. Then every year the figure only decreases.

For clarity, a cartogram was constructed for the figure of the number of graduates for 2018 (figure 1$)^{6}$. 
Figure 1 - Number of graduates of higher educational institutions of the Russian Federation in 2018

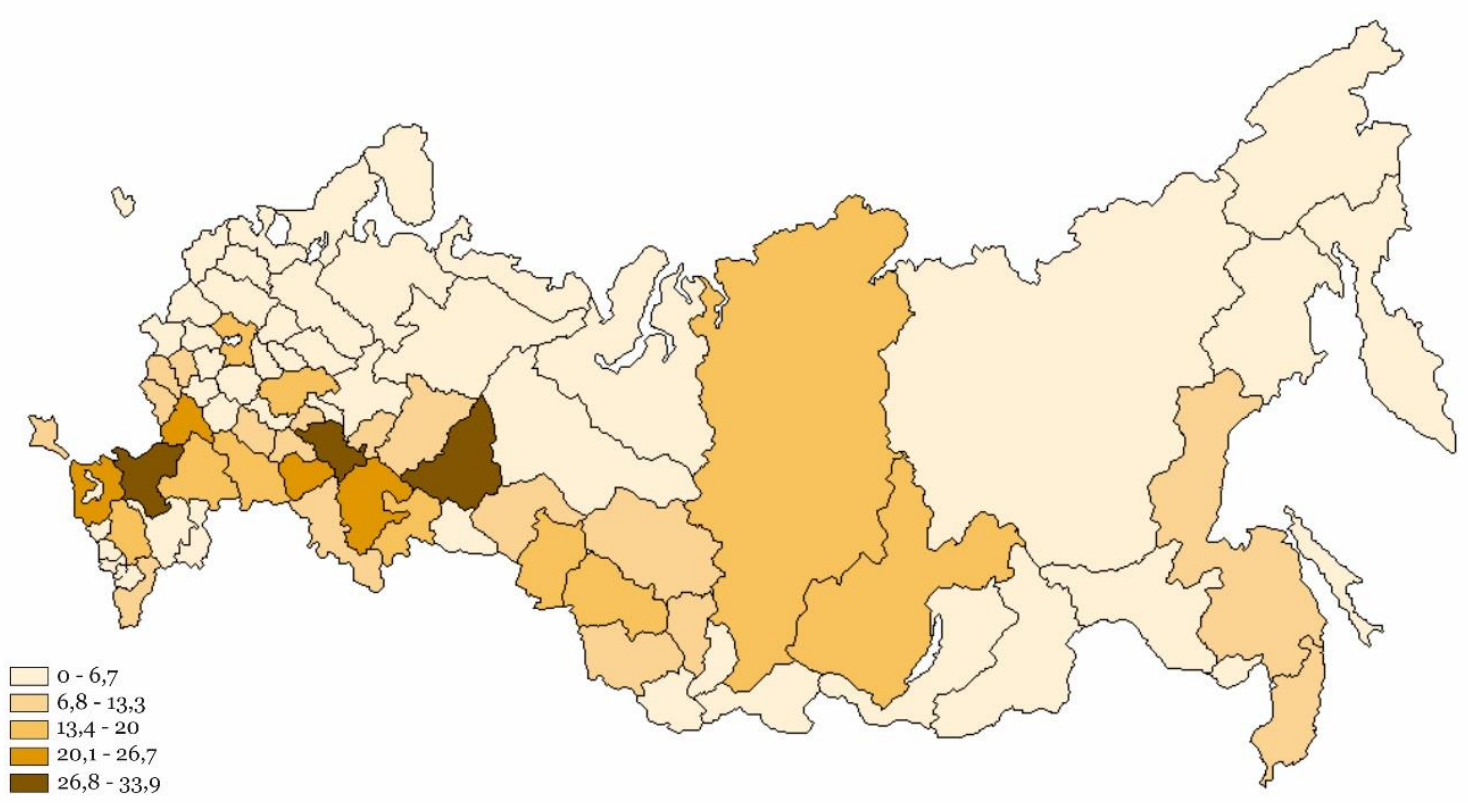

Source: Devised by the authors

Almost all the regions of the Far Eastern Federal district, with some exceptions, the Primorye and Khabarovsk territories, also the regions of the North Caucasus Federal district except for the Republic of Dagestan, the Northern and the Western Federal district, the Central Federal district (which, in their dynamics over the study period worsened the performance), regions KHMAO, YNAO, the Republic of Altai, Republic of Tuva and Republic of Khakassia are in the first group with the number of graduates from 0.1 to 9 . Belgorod, Kursk, Moscow regions are not in this group.

The second group with an average of 6.8 to 16.3 thousand graduates includes the following regions: Primorsky Territory, Khabarovsk Territory, Tomsk and, Kemerovo regions, Altai Territory, we included here the Tyumen region without autonomous area, its performance dropped over the past 3 years, Orenburg and Penza regions, Perm Territory, Chuvash Republic, Udmurt Republic, Republic of Crimea, Belgorod region and Kursk region.

The third group included: Omsk, Novosibirsk, Saratov, Nizhny Novgorod and Irkutsk regions, Krasnoyarsk and Stavropol territories, because their indicators fell down steeply with a difference of 10 thousand people, the Volgograd region, the Republic of Dagestan. Moscow and Voronezh regions are also in the third group due to their decreasing indicators.

In the fourth group there are the regions with indicators ranging from 20.1 thousand to 36 thousand people. This group includes: the Chelyabinsk region, without considering its last 
worst indicator, which does not reflect the dynamics, the Samara region, the Republic of Bashkortostan.

The last group includes regions with the best output indicators in values of 27 thousand or more. These are the Sverdlovsk region, the Republic of Tatarstan with the best indicators, the Rostov region and the Krasnodar territory. According to this point, we can draw the following conclusion: a huge number of subjects of the Russian Federation have a regression in the number of students graduating, which is clearly visible in comparison with Fig. 1 and Fig. 2, perhaps the impact is due to the growing influence of large educational institutions, as well as due to uneven population migration and population decline in individual regions. Between the city of Moscow and the subjects of the Russian Federation, there is a huge difference in values, and it only increases every year.

In order to find the number of higher education institutions per 10,000 inhabitants, we calculated it as the ratio of the number of higher education institutions per the total population and multiplied by 10,000. They showed the dynamics of this indicator from 2014 to $2018^{7}$. It was considered the differentiation of Federal districts and regions of the Russian Federation.

Studying the dynamics for Federal districts from 2014 to 2018, we found out that the highest values were observed in 2014 , and then we saw a decrease in the indicator over the following year.

The highest indicators were concentrated in the Central Federal district, both in 2014 and 2018. And the lowest indicators were in 2014 in the Ural Federal district (47), and in 2018 the lowest indicators were concentrated in the southern Federal district (37).

The cartogram was built to illustrate the indicator of the number of higher education institutions per 10,000 inhabitants in 2018 (figure 2$)^{8}$ 
Figure 2 - Number of higher education institutions per 10,000 inhabitants in 2018

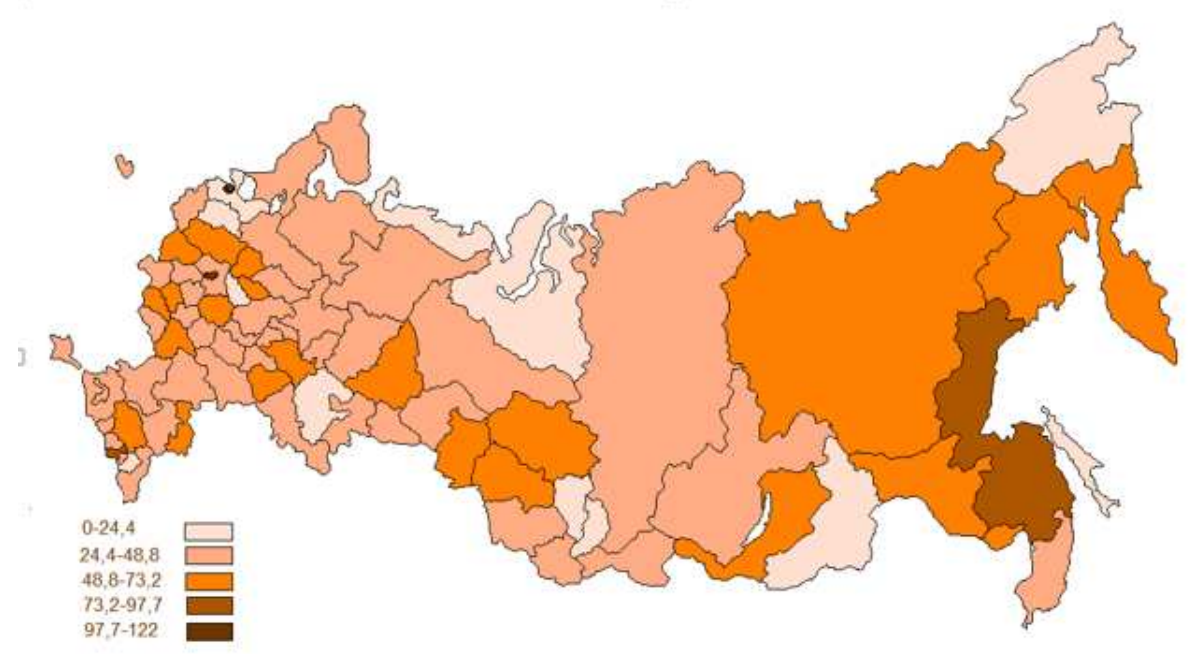

Source: Devised by the authors

After reviewing and analyzing the indicator in 2018, it was found out that the highest values were represented in the city of Moscow and the city of Saint Petersburg and, surprisingly, the highest values are concentrated in the Republic of North Ossetia-Alania and the Khabarovsk territory.

The lowest values were in the Leningrad region, the Novgorod region, the Republic of Khakassia, the TRANS-Baikal territory, and the Vladimir region. Unfortunately, the YamaloNenets Autonomous district and the Nenets Autonomous district did not have any indicators at all.

Thus, we applied methods of dividing indicators and grouping, which allowed us to make cartograms and visualize the differentiation of regions by the number of higher education institutions and the number of graduates.

\section{Summary}

Thus, the obtained results of the regression model indicate the need to invest in research and development and attract highly qualified personnel to higher education institutions, since these indicators have an impact on the socio-economic development of the region. Regions included in the fourth group (figure 1) by the number of graduates of higher education institutions have a rich potential for accelerated socio-economic development, such as the Chelyabinsk and Samara regions and the Republic of Bashkortostan. The regions of the fifth group already have high socio-economic indicators. 


\section{Conclusion}

Higher education is a driver of socio-economic development, being a direct alternative to resource development. Important indicators of higher education are the quality characteristics of teachers and research and development. Their subjective quantitative indicator of the accounting is their costs. Using a cost-based approach, it was possible to identify their impact on the region's GRP. An important criterion for the quality of higher education is the university professors' workload, for this reason we studied the indicator of the number of students per a professor. The volume of graduates of higher educational institutions has a direct impact on the formation of labor potential.

ACKNOWLEDGEMENTS: The study was supported by the Council for grants of the President of the Russian Federation, project no.MK-2702.2019.6. The work is performed according to the Russian Government Program of Competitive Growth of Kazan Federal University.

\section{REFERENCES}

BOURDIEU, P. Translation by M. S. Dobryakova. Scientific editing-V. V. Radaev Center for humanitarian technologies. Forms of Capital. Economic Sociology, v. 6, n. 3, p. 60-74, 2019. Available: http://gtmarket.ru/laboratory/expertize/2009/2601. Access: 06 Oct. 2019.

FAKHRUTDINOVA, A. V. Reforming Professional Education in Europe as a Condition for Improving its Competitiveness. Scientific notes of the Kazan State Academy of Veterinary Medicine Named After N. E. Bauman, v. 210, p. 247-251, 2012.

FEDERAL STATE STATISTICS SERVICE. Regions of Russia. Available: https://gks.ru/bgd/regl/b19_14p/Main.htm. Access: 21 Apr. 2020.

HUANG, J.; QIN, D. Tong Jiang \& Effect of Fertility Policy Changes on the Population Structure and Economy of China: From the Perspective of the Shared socio-Economic Pathways. Earth's Future, v. 7, 2019. DOI: 10.1029/2018EF000964

KARASIK, E. A. et al. Poverty overcoming problems of Russian population. Mediterranean Journal of Social Sciences, p. 1137, 2015.

KOLESNIKOVA, J.; FAKHRUTDINOVA, E.; ZAGIDULLINA, V. The structure of intangible capital. In: INTERNATIONAL CONGRESS ON INTERDISCIPLINARY BEHAVIOR AND SOCIAL SCIENCE, 4., 2015. Proceedings [...]. 2016. Theme: Social Sciences and Interdisciplinary Behavior. 
LOCHNER, L. Education, Work and Crime: A Human Capital Approach. International Economic Review, v. 45, p. 78, 2004.

MADDISON, A. Dynamic Forces in Capitalist Development. Oxford: Oxford University Press, 1991.

TROKHIMCHUK, A. V. Influence of education on the economy in the conditions of postindustrial society. Scientific and methodological electronic journal "Concept", v. 14, p. 292-298, 2017. Available: http://e-koncept.ru/2017/770663.htm. Access: 22 May 2020.

ZUBAREVIC, H. N. V. Spatial Development Strategy: Priorities and Tools. Economic issue, v. 1, p. 135-145, 2019.

\section{How to reference this article}

FAKHRUTDINOVA, E. V.; KOLESNIKOVA, J. S.; LARIONOVA, N. I.; CHUMAROVA, L. G. Impact of higher education on socio-economic development. Revista on line de Política e Gestão Educacional, Araraquara, v. 25, n. esp. 6, p. 3472-3482, Dec. 2021. e-ISSN:15199029. DOI: https://doi.org/10.22633/rpge.v25iesp.6.16102

Submitted: $15 / 04 / 2021$

Required revisions: $29 / 08 / 2021$

Approved: 29/11/2021

Published: 30/12/2021

Processing and publication by the Editora Ibero-Americana de Educação. Correction, formatting, standardization and translation.

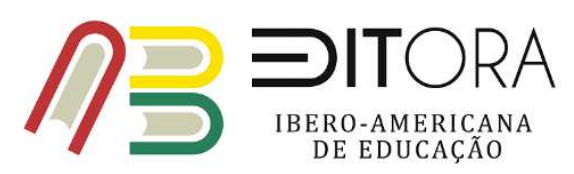

